1656

日本機械学会論文集 (C 編)

75 巻 754 号 $(2009-6)$

論文 No. 08-0898

\title{
管群を有するダクト内の音速評価に関する研究*
}

\author{
石 原 国 彦*1, 宮 本 高 徳*2, 吉田 侑 加*3
}

\section{Study on Evaluation of Sound Speed in Duct with Tube Banks}

\author{
Kunihiko ISHIHARA*4, Takanori MIYAMOTO and Yuka YOSHIDA \\ ${ }^{* 4}$ Institute of Technology and Science, The University of Tokushima, \\ 2-1 Minami-Jyosanjima-cho, Tokushima-shi, Tokushima, 770-8506 Japan
}

\begin{abstract}
As tube banks are set in a duct in a boiler and a heat exchanger, the resonance phenomenon or the self sustained tone are generated due to the interference between a vortex shedding and an acoustic characteristics of duct. It is necessary to know the resonance frequency of the duct, namely sound speed, for avoiding any trouble that may arises. In general, it is said that the sound speed decreases in the duct with tube banks and an evaluation formula is given. However this formula is obtained to apply to the perpendicular direction to the flow. We want to know that this formula is able to apply to the flow direction and to various array patterns or not. Then in this paper, applicability limit of this expression is discussed by using FEM analysis and experiments.
\end{abstract}

Key Words: Sound and Acoustic, Noise Control, Prediction, Wave, Sound Speed, Tube Bank

\section{1. 腥 言}

ボイラや熱交換器では, ダクト内に管群を設置 し，各管の内部に水を外部に高温ガスを流して熱交 換を行う．その際，各管の背後にはガス流速に比例 したカルマン渦が生じダクト内音場を励振させる.

一方ダク卜内湆場を形成しており，音速とダ クト寸法で決定される共鳴周波数を持つ. したがっ てカルマン渦の脱落周波数とダクト音場の共鳴周波 数が一致するガス流速ではいわゆる父柱共鳴現象を 起こしたり，ダクト音場の音響减衰が小さい場合は ガス流速が共鳴点を通過しても大音響が持続するい わゆる空力自励音が発生する.これらの現象がひと たび発生すると工場周辺住民かららの苦情により操業 停止に追い込まれたり，対策工事に多大な費用が発 生する.したがって設計段階において気柱共鳴や空 力自励音が発生しないよう十分な検討が必要となる。

そのためには設計段階において音速の正碓な把 握が必要であり，ダクト内に管群が置かれた音場で は従来 Parker ${ }^{(1)}$ や Blevins ${ }^{(2)}$ が提唱した充填率 $\sigma$ (管 群部における管の占める体積割合）と音速との関係 式 $c / c_{0}=1 / \sqrt{1+\sigma}$ を使用してきた。ここで $c$

* 原稿受付 2008 年 10 月 2 日

*1 正員, フェロー, 徳島大学大学院ソシオテクノサイエンス研 究部 (函 770-8506 徳島市南常三島町 2-1).

*2 学生員, 徳島大学工学部.

*3 徳島大学工学部.

E-mail : ishihara@me.tokushima-u.ac.jp
と $c_{0}$ はそれぞれ管群が有る場合と無い場合の音速 である.この式は音速が克填率 $\sigma$ のに依存してお り，充填率が同じであれば配列のパターンが異なっ ても適用できるかという疑問がある.

そこで，本論文ではまずこの式の理論的背景を 理解した上で，ダクト内に管群を種々の充填率で設 置し，FEMでの解析と実験を行い，この式の有用 性を調べ，適用限界を明らかにすることを目的とす る.

\section{2 主な記号}

$\mathrm{a}:$ 付加マス係数

$\sigma$ : 充填率（管群部における管の占める体積割合）

$c_{0}$ : 管群が無、場合 $(\sigma=0)$ の音速

$c_{e}$ : 管群が有る場合 $(\sigma \neq 0)$ の音速

$d:$ 管外径

$\mathrm{f}:$ 単位体積当たりの力ベクトル

$\rho:$ 流体密度

$p:$ 压力

$\mathrm{Q}$ : 単位体積当たりの質量変化割合

$\mathrm{U}:$ 流速ベクトル

$\mathbf{u}(\mathbf{t})$ : 変動流速ベクトル

$\mathbf{u}: \mathbf{x}$ 方向の流速

$\mathrm{V}$ : 仮想管で占有されている体積

$\lambda$ : 音波の波長 
$\mathrm{t}$ : 時間

$\nabla:$ 微分作要素（ナブラ）

$\mathrm{U}_{0}, \quad \rho 0 . \quad p_{0} \sigma$ 添え字 0 は平均量を示す.

\section{3. 理論の概要}

理論については既に Blevins が文献りにおいて示 しており，ここではそれを引用し，著者の解釈を交え て述べる。

非粘性流体における連続の式と運動量の式は次式 で与えられる。

$\frac{\partial \rho}{\partial t}+\nabla \cdot(\rho \mathbf{U})=Q$

$\rho \frac{\partial \mathbf{U}}{\partial t}+(\rho \mathbf{U} \cdot \nabla) \mathbf{U}=-\nabla p+\mathbf{f}$

$\mathbf{U}=\mathbf{U}_{0}+\mathbf{u}(t), \quad \rho=\rho_{0}+\rho(t), \quad p=p_{0}+p(t)$

(3)

として式（1），（2）に代入し，高次項を省略し平 均流を差し引くと

$\frac{\partial \rho}{\partial t}+\rho_{0} \nabla \cdot \mathbf{u}+\mathbf{U}_{\mathbf{0}} \cdot \nabla \rho=Q$

$\rho_{0} \frac{\partial \mathbf{u}}{\partial t}+\rho_{0} \mathbf{U}_{\mathbf{0}} \cdot \nabla \mathbf{u}+\rho \mathbf{U}_{\mathbf{0}} \cdot \nabla \mathbf{U}_{\mathbf{0}}+\rho_{0} \mathbf{u} \cdot \nabla \mathbf{U}_{0}+\nabla p=\mathbf{f}$

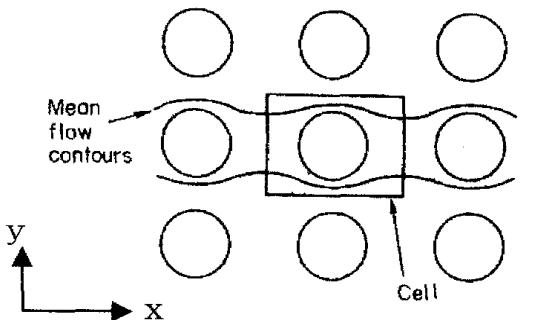

(a) $\frac{1}{c_{0}^{2}} \frac{\partial p}{\partial t}+\rho_{0} \nabla \cdot \mathbf{u}=Q$

$\rho_{0} \frac{\partial \mathbf{u}}{\partial t}+\nabla p=\mathbf{f}$

となる。

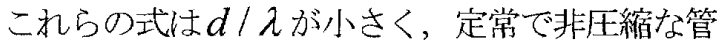
が規則的に配置された中を通る音の伝播を記述する

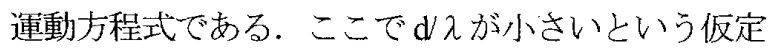
は流体騒音の解析に通常用いられる音響的にコンパ クトを意味するものである。

まず流体と管の間に作用する力を計算する，物理 的な管はそれらの管が流体に与える力で置き換えら れる，図 1(b)に示弾位セル内の管によって占めら れる部分 $\sigma$ を流体密度 $\rho$ と音速 $c_{0}$ の王縮性流 体で置換する，実際の管を模擬するために，体積力 壬とQが仮想管の領域に次のように作用するとす b.

仮想管の流体領域は

(1) 圧縮されない.

（2）定常に保たれる.（同じ位置に固定され，変 形しない)

（3）渦脱落や減衰に関連するような力を与える. 圧力 $p$ の増加は，仮想管で占有されている領域 $\sigma の$ 体積 $V$ を $\delta V$ だけ圧縮させる.すなわち

$\frac{\delta V}{V}=-\frac{\delta \rho}{\rho}=-\frac{\delta p}{\rho c_{0}^{2}}$

仮想管が占める領域の単位体積当たりの対応する流 体質量は

$\sigma \frac{\delta m}{V}=\sigma \frac{\rho \delta V}{V}=-\sigma \frac{\delta p}{c_{0}^{2}}$

(b)

Fig.1 Model of tube

もし，この流体質量が仮想管が占める領域の中八 注入されるとしたら，仮想管の体積は圧縮されない. そこに必要なマスフラックスは

$Q=-\left(\frac{d}{d t}\right)\left(\frac{\sigma \delta m}{V}\right)=\left(\frac{\sigma}{c_{0}^{2}}\right) \frac{\partial(\delta p)}{\partial t}$

これは，非圧縮管の効果を模擬するために，流体 セルの中に注入されなければならない平均マス流体 である。

次に一様流速 $\mathrm{U}_{0}$ が管の有無による流路幅の拡大 縮小により加減速されるとき流れ場は円柱に付加マ スを与える。

$f_{\text {addedmass }}=\rho_{0}(1+a) \frac{\partial u}{\partial t}$

これは円柱の単位体積あたりに付加される力であ 3 . 
右辺第 1 項は圧力公配に起因守る浮力であり，第 2項は仮想質量力である。

$a$ は付加マス定数で, 単一円柱では理論的に 1.0 となる. セルの単位体積あたりの対応寸る力は $\sigma f$ である．したがって円柱が占有体積率 $1-\sigma$ の流体 に与える付加される力は

$f=-\left[\rho_{0} \sigma(1+a) /(1-\sigma)\right] \frac{\partial u}{\partial t}$

となる。

簡単のため, 低ソリディティで一方向伝播（図 1 の $\mathrm{x}$ 方向）に限定して考察する. 実際には，これは まばらな管群に限定 $(\sigma<1)$ され，付加マス係数 で特徴付けられる一方向伝播に限られるものである.

式（10）と（11）を式（8）と（9）に代入すると それぞれ

$\frac{1-\sigma}{c_{0}^{2}} \frac{\partial p}{\partial t}+\rho_{0} \frac{\partial u}{\partial x}=0$

$\rho_{0}\left[1+\left\{\frac{\sigma}{1-\sigma}\right\}(1+a)\right] \frac{\partial u}{\partial t}+\frac{\partial p}{\partial x}=0$

ここで $u$ は $x$ 方向の波動伝播に関連する粒子速 度であり圧力 $\mathrm{p}$ は時間変動分の $\delta p$ 示示。

式（12），（13）より $u$ を消去すると次式を得る.

$\frac{1}{c_{e}^{2}} \frac{\partial^{2} p}{\partial t^{2}}-\frac{\partial^{2} p}{\partial x^{2}}=0$

ここで

$c_{e}=\frac{c_{0}}{\sqrt{1+\sigma a}}$

したがって管群の等価音速 $c_{\mathrm{e}}$ は管があることで 小さくなる，音速が減るのは下記に示すような

（1）管の存在による有効密度の増加之（2）有效体 積弾性率の減少の結果である.

すなわち，

（1）圧力の増加 $\rightarrow$ 仮想管の体積が小さくなる. $\rightarrow$ しかし管は圧縮されないい体積が小さくなら ないだけQが管領域に注入されなければな

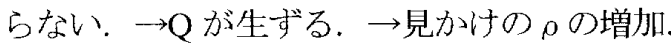

（2）加速流れ 流れが円柱に付加マス力を与える. 、しかし円柱は動かない，＜wide>ととすれば逆に円 柱が流体に力を与えなければならない， $\rightarrow \mathrm{f}$ が生じる. ↔見かけの圧縮性の増加 一有効体 積弾性率 $\mathrm{K}$ の減少（定義 $K=d p /(-d v / v)$ より).

$\sigma$ が比較的小さい場合， $a \approx 1$ で式（13）は Parker の式(16)となる.

$$
c_{e}=\frac{c_{0}}{\sqrt{1+\sigma}}
$$

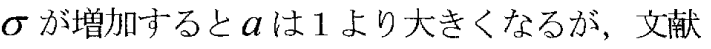
(2)ではいくらの值になるか恃されていない，ま た式(15)，(16)唒列パターンには份存しないと記 述しているが以下の章ではこれらのことも含めて検 討する。なおここで述べた理論では平均流 $\mathrm{U}_{0}$ の 影響は無視したが，文献（6）によれば無次元振動 数 $\omega \mathrm{d} / \mathrm{U}_{0}$ の值が 5.0 以上であれば平均流の音速への 影響はないとされており，実機では一般にこの基準 が満たされている場合が多いことから平均流の影響 は考慮しなくてもよいと考えられる.

\section{4. 解 析}

ここでばダクト内に管群がある場合とない場合に いて有限要素法により共鳴周波数の值を計算し，乙 の比が音速の比であることから式(16)との比較をおこ ない，この式の有用性を検討し適用限界を調べる.

\section{1 有限要素解析モデル}

2 次元， 3 次元モデルの $\mathrm{x}$ 方向（ダクト全長）を $2 \mathrm{~m}$, $\mathrm{y}$ 方向（流孔直角方向長さ）を $0.6 \mathrm{~m}$ とし，3 次元モ デルにおいては $\mathrm{z}$ 方向（高さ）を $0.2 \mathrm{~m}, 0.4 \mathrm{~m}, 0.6 \mathrm{~m}$ と変化させた。 またダクトモデル内には円管を作成し, 半径 $\mathrm{R}$ ，管本数 $\mathrm{N}$ ，充填率 $\sigma$ をパラメー夕とする. た だし, 各管配列において, 流れ方向ピッチ, 流れ直角 方向ピッチを統一した格子配列によってモデルを構成

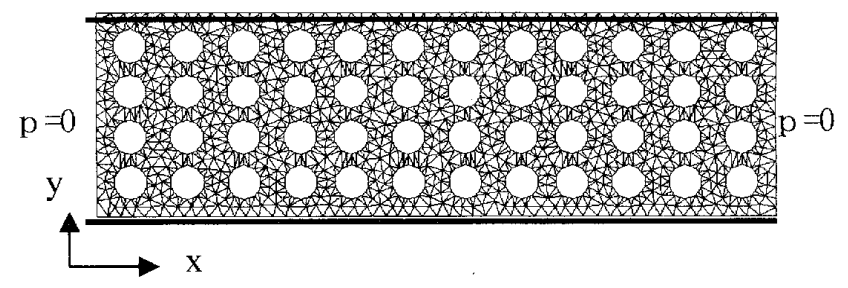

Fig.2 Twodimensionalmodel ( $\sigma=0.3$, 48tubes)

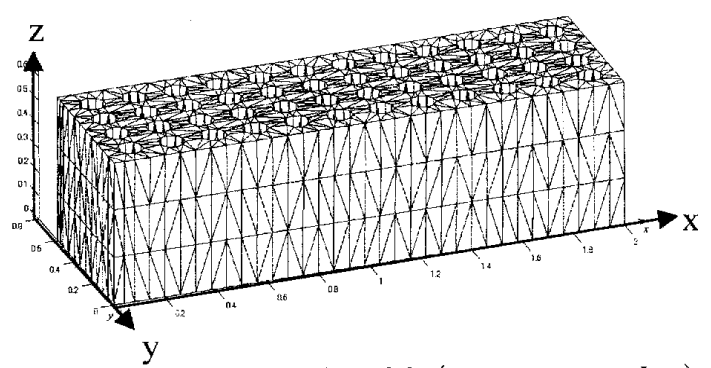

Fig.3 Three dimensional model ( $\sigma=0.3,48$ tubes)

する. 図 2，3に 2 次元および 3 次元におけるそれぞ れの解析モデルの一例を示寸，境界条件はダクト入口， 出口で圧力 $\mathrm{p}$ が零, ダクト壁面の法線方向の粒子速度 が零である. 


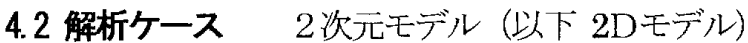

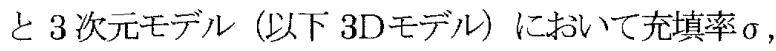
管半径 $\mathrm{R} ＼mathrm{~ ， 管 本 数 ~} \mathrm{~N}$ を与之解析を行う，なお，管の 半径を変えることにより同充填率で本数の異なるモデ ルを作成した，以下表1亿解析ケ一スを示寸。

4.3 解析結果 まず各管配列における解析を行う 上での 3D モデルの高さの分割数を決める. そこで, 高さ $0.6 \mathrm{~m}$ ，充填率 $\sigma=0.3$, 管本数 $\mathrm{N}=12$ の場合での各 次モ一ドにおける共鳴周波数の值を計算したところ $\mathrm{z}$ 方向の分割数を変えても図 4 に示すように変化がなか った，そのため，ここでの各管配列における解析は $\mathrm{z}$ 方向を 3 分割で行った.

Table1 Analysis cases

\begin{tabular}{|c|c|c|c|c|c|}
\hline$\sigma$ & $\mathrm{R}[\mathrm{m}]$ & $\mathrm{N}$ & $\sigma$ & $\mathrm{R}[\mathrm{m}]$ & $\mathrm{N}$ \\
\hline 0.201 & 0.04 & 48 & 0.531 & 0.13 & 12 \\
\hline 0.201 & 0.08 & 12 & 0.101 & 0.04 & 24 \\
\hline 0.314 & 0.05 & 48 & 0.226 & 0.06 & 24 \\
\hline 0.314 & 0.1 & 12 & 0.307 & 0.07 & 24 \\
\hline 0.452 & 0.06 & 48 & 0.402 & 0.08 & 24 \\
\hline 0.452 & 0.12 & 12 & 0.509 & 0.09 & 24 \\
\hline 0.531 & 0.065 & 48 & 0.113 & 0.06 & 12 \\
\hline
\end{tabular}

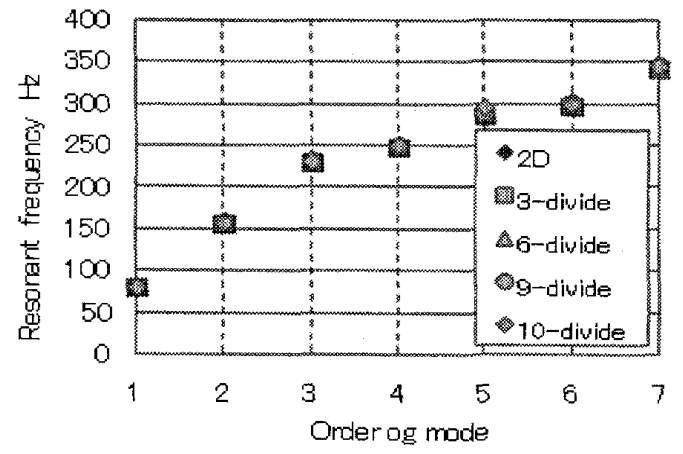

Hig.4 Comparison of resonant triequency by division number in analysis

\subsubsection{D モデルと 3Dモデルとの比較}

充填率 $\sigma=0.3$, 管本数 $\mathrm{N}=48$ の場合を例にとり $2 \mathrm{D}$ モデルと $3 \mathrm{D}$ モデルにおいて高さ $0.2 \mathrm{~m}, 0.4 \mathrm{~m}, 0.6 \mathrm{~m}$ をパラメータとしてx方向モードについての結果を 図5に，x，y連成モ一ドの結果索図6にそれぞれ 示す。また，式（16）で求まる音速を用いて算出 した共鳴周波数の計算値（これを理論值と呼ぶ）を 実線で示しそれぞれ比較を行う。ただし $\mathrm{c}_{0}=340 \mathrm{~m} / \mathrm{s}$ とした.

図5, 図6より充填率 $\sigma=0.3$ に执いて $2 \mathrm{D}, 3 \mathrm{D}$ 解析 共に共鳴周波数の值は理論值と非常に近い值が得られ た。また図5からおかるようにx方向モードの場合は，
3次モードまで理論值によく一致している。ここでは 割愛したが, 充填率 $\sigma=0.2$ 以内では高次モードまで理

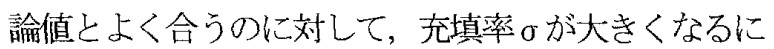
つれて理論值とのずれが低次モ一ドに及び，解析值は 理論值より小さくなる傾向が見られた. また図6から わかるように，x，y連成モ一ドの場合も理論值とよ く合った.ここて図6に沶いて（）内の数值（m, n) はx方向のモード次数 $\mathrm{m}, \mathrm{y}$ 方向のモード次数 $\mathrm{n}$ 老表す。

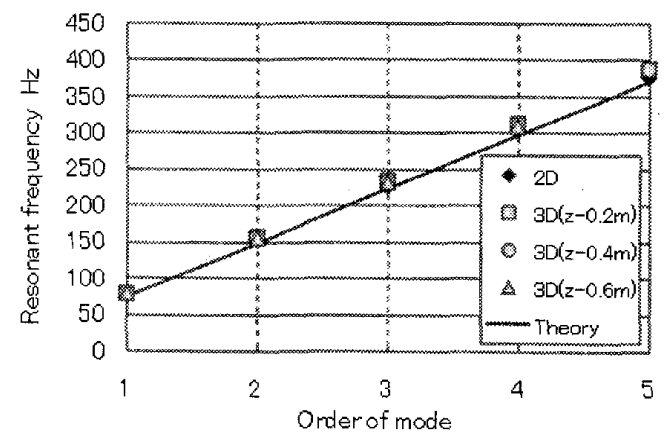

Fig .5 Comparison of analysis value with theoretical value of resonant frequency of $\mathrm{x}$-direction-mode ( $\sigma=0.3,48$ tubes)

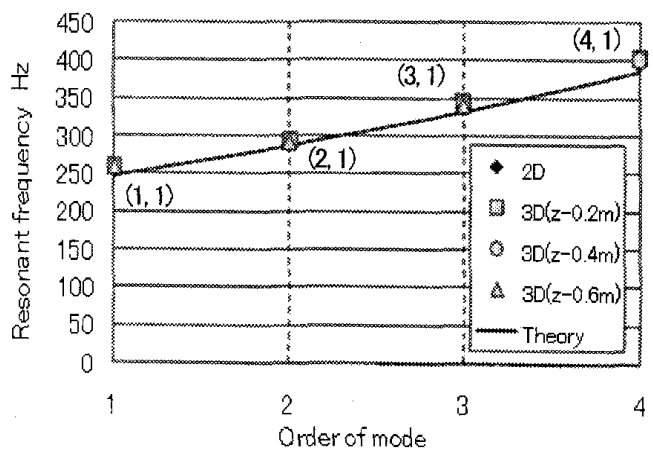

Fig .6 Compaison of analysis value with theoretical value of resonant frequency of $x, y$-coupled-mode $(o=0.3,48$ tubes $)$

\section{3.2 充填率と管本数の共鳴周波数に及ぼす影響 ( $x$ 方向) について}

図 7 に充填率 $\sigma=0.3$ の場合について本数の影響を示 す.また，図8に管本数 $\mathrm{N}=24$ の場合について充填率 の影響を示す。ここで半径をパラメータとすることで 同充填率における管本数による影響，同樣に充填率を パラメータとすることで同じ管本数における充填率の 影響を解析により考察した。

図 7 と図 8 見ると $\mathrm{x}$ 方向モードの場合は，本数 の共鳴周波数に及ぼす影響はあるものの立填率の影 響の方が大きい，また充填率が大きくなるにつれて 理論值とのずれが高次モードに及び，解析値は理論 値より低くなる傾向がみられた（図 9参照）。ここ では割愛するが $\mathrm{x}, \mathrm{y}$ 連成モードの場合は，低次で は理論值より大きくなっており，高次モードになる 
ほど理論值に一致している。これは $\mathrm{x}$ 方向モードの 場合とは逆の傾向である．また充填率が大きいほど 低次モードでのばらつきも大きくなっている.

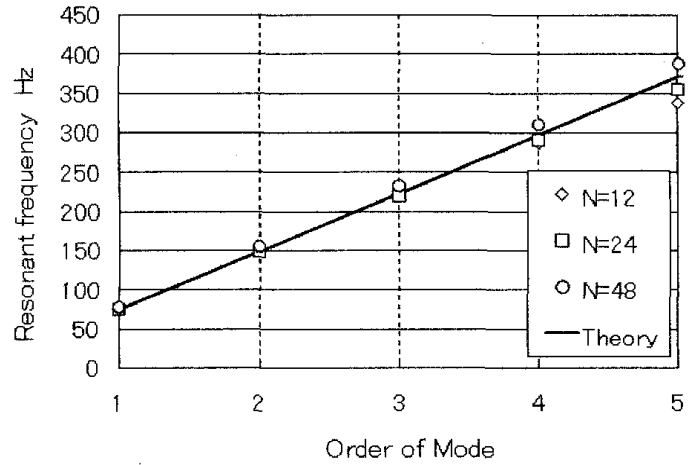

Fig .7 Resonant frequency of the effect on number of tubes $(\sigma=0.3,3 \mathrm{D}$-height $0.4 \mathrm{~m})$

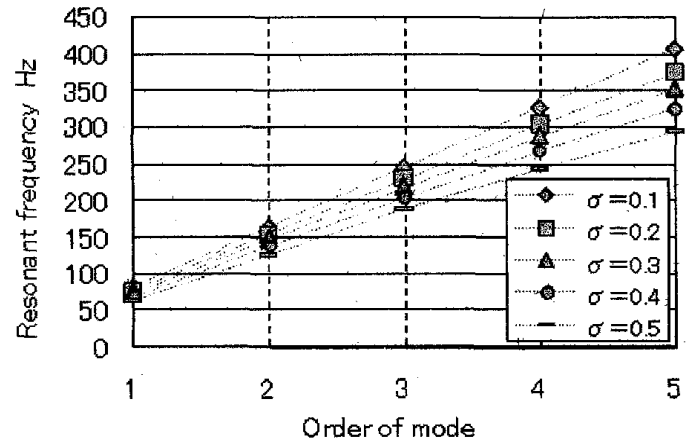

Fig. 8 Resonant frequency of the effect on occupied area ratio (24Tubes, 3D-height $0.4 \mathrm{~m}$ )

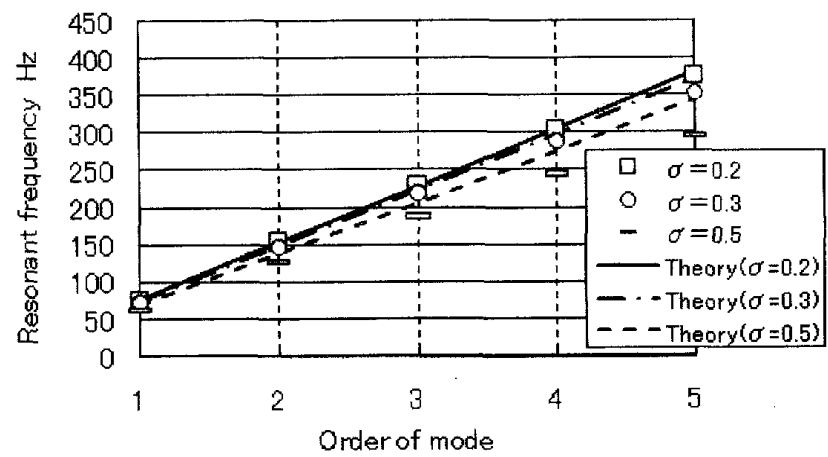

Fig .9 Comparison of analysis value with theortical value of resonant frequency $(\sigma=0.2, \sigma=0.3, \sigma=0.5)$

\subsection{3 音速と充填率の関係式の修正 Parker の} 理論式(16)による共鳴周波数の理論值と解析值を比 較すると前述のとおり充填率が大きく（ $\sigma=0.3$ 以 上）なると高次モードほど共鳴周波数の理論值より 解析值は小さくなる結果が得られた。 そのため， $\sigma$ が大きい場合, 理論式（16）に補正係数 aを与えた 式（17）による理論值と解析值とを比較をした． 2 $\mathrm{D}$ モデルにおける $\sigma=0.3$ の場合の結果を図 10 に示 す. $\sigma=0.2$ 以内では $=1$ で理論值と合っており（図
9参照）， $\sigma=0.3$ の時は $\mathrm{a}=1.35, \quad \sigma=0.4$ の時は $\mathrm{a}=1.6$, $\sigma=0.5$ の時は $\mathrm{a}=2.0$ とすると解析結果と理論值がよ く合った，そして，各充填率 $\sigma$ に対寸る補正係数 $\mathrm{a}$ を表すと図 11 のようになり，ほぼ直線上になるこ とから，関倸式（18）が得られた。

$$
\begin{gathered}
\frac{f_{n}}{f_{n 0}}=\frac{1}{\sqrt{1+a \sigma}} \frac{c}{c_{0}} \\
a=(10 / 3) \sigma+1 / 3
\end{gathered}
$$

ここで $f_{\mathrm{n}} ｆ_{\mathrm{n} 0}$ はそれぞれ管が有る場合と無い場合 のダクトの共鳴周波数である。

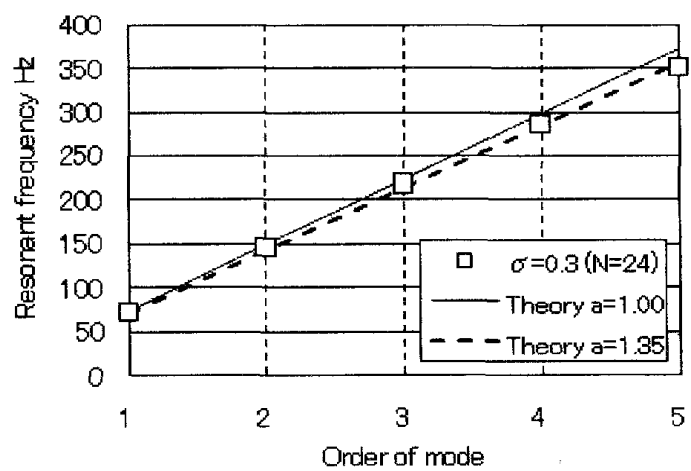

Fig.10 Compensation of theoretical formula $(\sigma=0.3)$

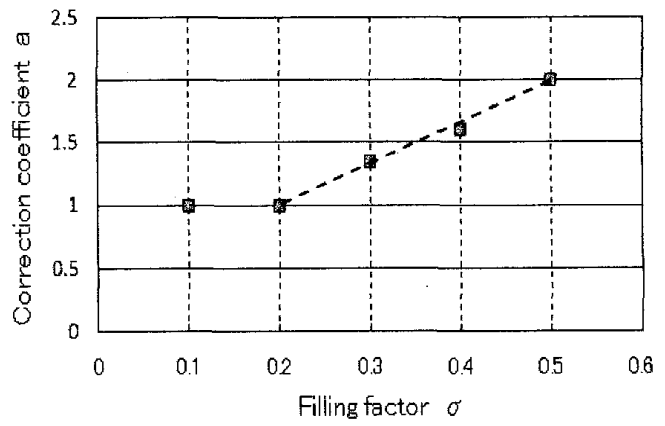

Fig.11 Rektion between occupied area ratio and conection factor

\section{5. 実 殹}

5.1 実検装置 図 12 に示すように全長 $1000 \mathrm{~mm}$ のダクト(材料：アクリル)の上流にスピーカを設置す る. 流路の断面は $200 \mathrm{~mm} \times 250 \mathrm{~mm}$ である. ダクト内 に直径 $\mathrm{d}=26 \mathrm{~mm}$ の塩ビ管を挿入し，種々の管配列を 構成する.

5.2 実験ケース 実験ケースを表 2 に示寸。ここ

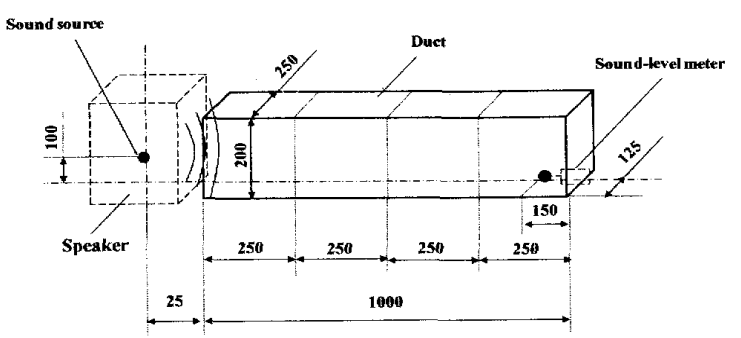

Fig12 Experimental apparaus
Unit : mm 
Table2 Occupied area ratio of various cases

\begin{tabular}{|c|c|c|c|}
\hline$\overbrace{T / d} / / d$ & 1.5 & 2.0 & 2.5 \\
\hline 1.5 & (1) 0.306 & (5) 0.255 & (7)0.204 \\
\hline 2.0 & (4) 0.255 & (2) 0.212 & (9) 0.170 \\
\hline 2.5 & (6) 0.204 & (8) 0.170 & (3) 0.136 \\
\hline
\end{tabular}
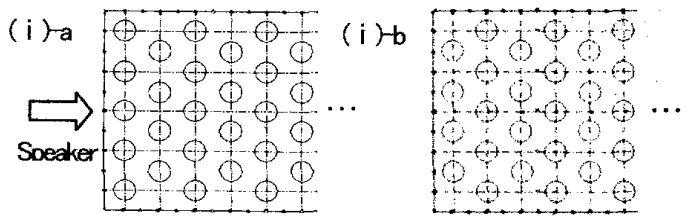

(ii) $-a$

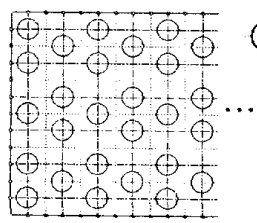

(ii) b

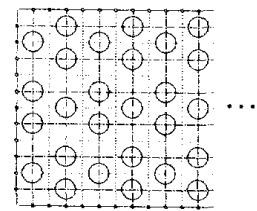

Fig.13 Tube array and size $(\mathrm{T} / \mathrm{d}=1.5, \quad \sigma=0229)$
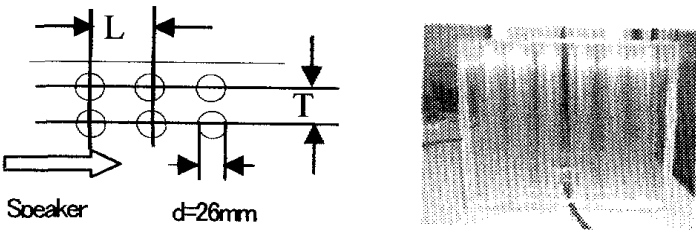

Fig.14 Tube array and size

で(1)，(2)，(3)は正方配列で，(4)と(5)，(6)上(7)および8) と(9)はそれぞれ充填率が同じで配列が異なる場合であ る. また，千鳥配列において，図 13 に示すように, それぞれ同充填率 $\sigma=0.229$ であり, 流れ方向ピッチ L の比率を統一して構成した 4 通りの場合において実験 を行った.

\section{3 計測方法 図14のようにダクト内に塩ビ} 管を扦入し，図 12 に示すようにダクト上流加ら ピーカにより純音を送り，周波数を $1 \mathrm{~Hz}$ 毎に変え， 各周波数において図 12 の右端から $150 \mathrm{~mm}$ におかれ たマイク位置での音圧レベルを計測する．その結果 から音圧レベルがピークとなる周波数を共鳴周波数 とし，各管配列における実験での 1 次，2次モード の共鳴周波数の值と理論式を用い求めた共鳴周波数 の值（予測值 $\mathrm{f}_{\mathrm{n} \mathrm{pre}}$ ) とを比較する.

表 2 に示したパラメータであるダクト内の管群の 充填率 $\sigma$ は管群の流れ方向ピッチ L と流れ直角方向 ピッチ Tの比率を変えて取り変えられる（図 13 参
照）。また千鳥配列においても表 2 に示すピッチを 元に同様に実験し，比較を行う。

各管配列における共鳴周波数の予測值 $f_{\mathrm{n} \mathrm{pre}}$ の求 め方は管群ダクトの充填率と音速の関係式 (16) に より，まず各管配列での音速 $c_{e}$ を求め，次に $\sigma=0$ での共鳴周波数の值 $\mathrm{f}_{\mathrm{n} 0}$ を実験により求め, 式

（19）を用いて算出する. ただし， $\sigma=0$ における 音速 $\mathrm{C}_{0}$ は $331.5 \sqrt{ }((273+\mathrm{t}) / 273)$ で与える. ここで $\mathrm{t}$ は温度 $\left({ }^{\circ} \mathrm{C}\right)$ である。

$$
f_{n p r e}=f_{n 0} \times\left(C_{e} / C_{0}\right)
$$

\section{4 実験結果及び考察}

\subsection{1 管群を設置していない状態での共鳴周波数}

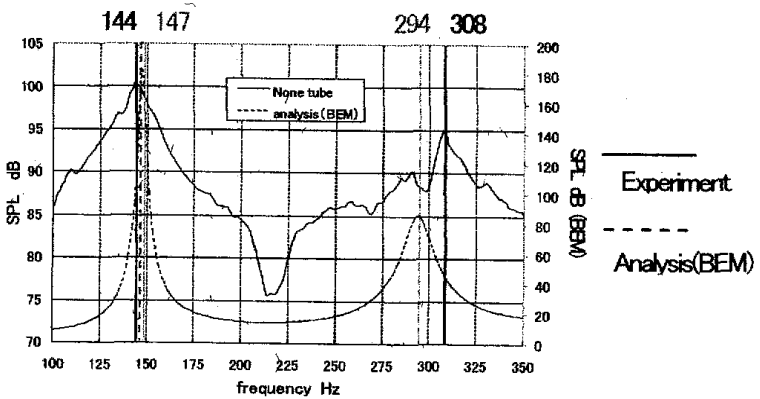

Fig. 15 Comparison of experimental value with analysis value of resonant frequency without tubes

図 15 は $\sigma=0$ でのダクトにおいて，各周波数に対す るマイク位置での音圧レベルの実験值を示寸：図中に は $\sigma=0$ での共鳴周波数の值（実線），また同じダク トモデルで害験と直接比較するため端部補正も含めて 解析ができる BEM(市販ソフトWAON) で求めた共鳴 周波数の值（破線）も示している. 1 次モードでは著 しい音圧のピーク值が実験から得られ，その共鳴周波 数の実験值は解析值とほぼ等しくなった. 2 次モード においては実験值と解析值に少しずれが生じたがモー ド波形を確認の上，144Hz，308Hzを $\sigma=0$ でのそれぞ れの 1 次と 2 次モードの共鳴周波数の実駼值 $\mathrm{f}_{0}$ とし た. そしてこれらの值を各管配列での共鳴周波数の予 測値を求める際に用い実験值と比較した.

\subsection{2 各管配列での共鳴周波数}

\section{(1) 実験値と予測值との比较}

表 3 に各ケースにおける 1 次, 2 次モードの共鳴 周波数の実験値/予測値を示す。また（）内の数 字は実験值を予測值で除した值である．また図 16 〜19 に示寸実線，破線はそれぞれ寒験值と予測值 の各管配列での共鳴周波数の位置とそれらの值を示 す. 
Table 3 Comparison of experimental value with predictive value of resonant frequency

\begin{tabular}{|c|c|c|}
\hline $\begin{array}{r}\text { Experimental value }(H z) \\
\text { Pridictive value }(\mathrm{Hz})\end{array}$ & $15 t$ & 2rd \\
\hline$\sigma=0$ & $\begin{array}{c}144 / 147 \\
(0.98)\end{array}$ & $\begin{array}{c}308 / 294 \\
(0.95)\end{array}$ \\
\hline $\begin{array}{l}1 \sigma=0.306 \\
L / d=T / d=1.5\end{array}$ & $\begin{array}{c}118 / 126 \\
(0.94) \\
\end{array}$ & $\begin{array}{c}262 / 270 \\
(0.97) \\
\end{array}$ \\
\hline $\begin{array}{l}3 \sigma=0.212 \\
L / d=T / d=2.0\end{array}$ & $\begin{array}{c}130 / 131 \\
(0.99) \\
\end{array}$ & $\begin{array}{c}277 / 280 \\
(0.97) \\
\end{array}$ \\
\hline $\begin{array}{l}\text { (3) } \sigma=0.136 \\
L / d=T / d=2.5\end{array}$ & $\begin{array}{c}(32 / 135 \\
(0.98)\end{array}$ & $\begin{array}{c}279 / 280 \\
(0.97)\end{array}$ \\
\hline $\begin{array}{l}60=0.255 \\
L / d=1.5, T / d=2.0\end{array}$ & $\begin{array}{l}129 / 129 \\
(1.00)\end{array}$ & $\begin{array}{c}275 / 275 \\
(1.00)\end{array}$ \\
\hline $\begin{array}{l}\sigma=0.255 \\
L / d=2.0, T / d=1.5\end{array}$ & $\begin{array}{c}125 / 129 \\
(0.97)\end{array}$ & $\begin{array}{c}270 / 275 \\
(0.94)\end{array}$ \\
\hline $\begin{array}{l}6 \sigma=0.204 \\
L / d=1.5, T / d=2.5\end{array}$ & $\begin{array}{c}128 / 131 \\
(0.98) \\
\end{array}$ & $\begin{array}{c}281 / 281 \\
(1.00) \\
\end{array}$ \\
\hline $\begin{array}{l}\sigma=0.204 \\
L / d=2.5 . T / d=1.5\end{array}$ & $\begin{array}{l}127 / 131 \\
(0.97)\end{array}$ & $\begin{array}{c}273 / 281 \\
(0.97) \\
\end{array}$ \\
\hline $\begin{array}{l}8, \sigma=0.107 \\
L / d=2.0, T / d=2.5\end{array}$ & $\begin{array}{l}131 / 137 \\
(0.96)\end{array}$ & $\begin{array}{l}280 / 293 \\
(0.96)\end{array}$ \\
\hline $\begin{array}{l}9 \sigma=0.107 \\
L / d=2.5 . T / d=2.0\end{array}$ & $\begin{array}{c}128 / 137 \\
(0.93) \\
\end{array}$ & $\begin{array}{c}278 / 293 \\
(0.95)\end{array}$ \\
\hline
\end{tabular}

Table 4 Comparison of experimental value with predictive value of resonant frequency at staggered tube array $(\mathrm{T} / \mathrm{d}=1.5, \quad \sigma=0.229)$

\begin{tabular}{|l|c|c|}
\hline $\begin{array}{c}\text { Experimental value }(\mathrm{Hz}) \\
\text { /predictive value }(\mathrm{Hz})\end{array}$ & 1st & 2nd \\
\hline ( i )-a $\sigma=0.229$ & $126 / 130(0.97)$ & $275 / 278(0.99)$ \\
\hline ( i )-b $\sigma=0.229$ & $125 / 130(0.96)$ & $269 / 278(0.97)$ \\
\hline (ii )-a $\sigma=0.229$ & $125 / 130(0.96)$ & $269 / 278(0.97)$ \\
\hline ( ii )-b $\sigma=0.229$ & $124 / 130(0.95)$ & $269 / 278(0.97)$ \\
\hline
\end{tabular}

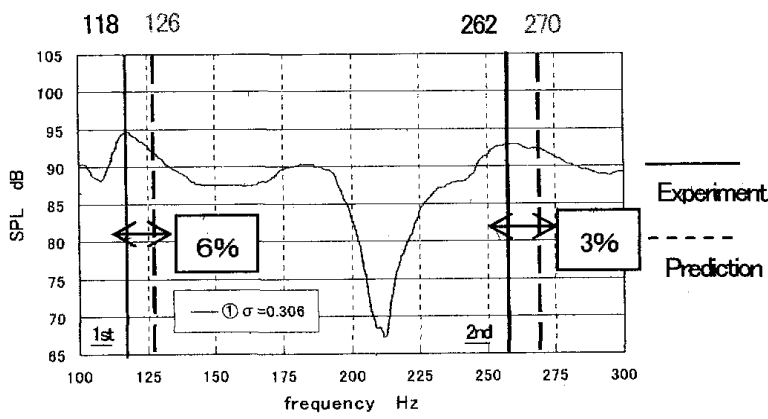

Fig.16 Experimental result at $\mathrm{L} / \mathrm{d}=\mathrm{T} / \mathrm{d}=1.5$

正方配列である図 16，17 および表 3 の(1)，(2)， (3)からわかるように 1 次, 2 次モードでは, 高充填 率 $(\sigma=0.306)$ では誤差が大きく (1st $6 \%$, 2nd 3\%), 低充填率（ $\sigma=0.212,0.136)$ では誤差が小さい. また，表 4 に示すように同充填率 $(\sigma=0.229)$ ・異配 列である千鳥配列において比較すると，ほぼ同じ共 鳴周波数の值となり，千鳥配列では配列パターンの 共鳴周波数の值に及ぼす影響はわずかであることが わわる。

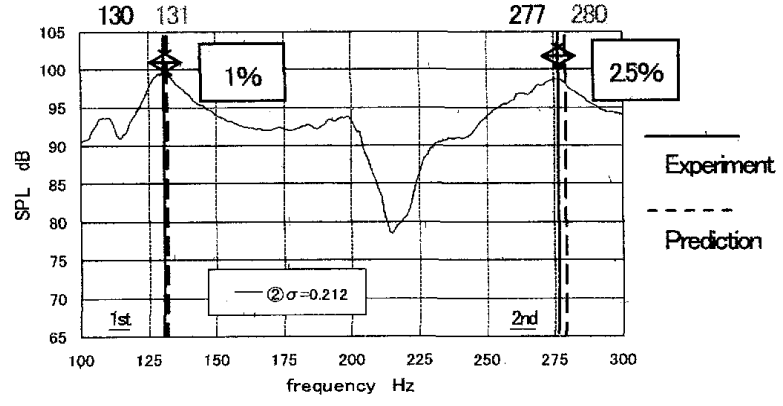

Fig. 17 Experimental result at $\mathrm{L} / \mathrm{d}=\mathrm{T} / \mathrm{d}=2.0$

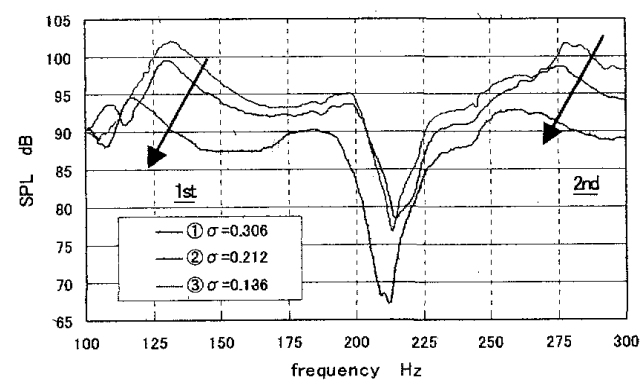

Fig.18 Comparison of R. frequency at square array

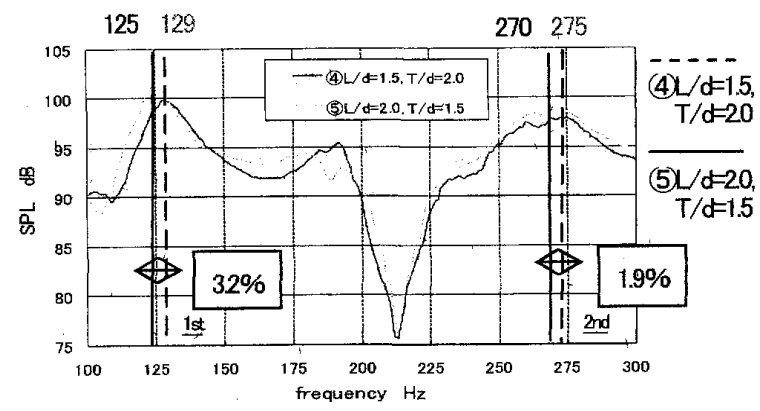

Fig.19 Comparison of resonant frequency at $\mathrm{L} / \mathrm{d}=1.5, \mathrm{~T} / \mathrm{d}=2.0$ with $L / \mathrm{d}=2.0, \mathrm{~T} / \mathrm{d}=1.5$ in $\sigma=0.255$

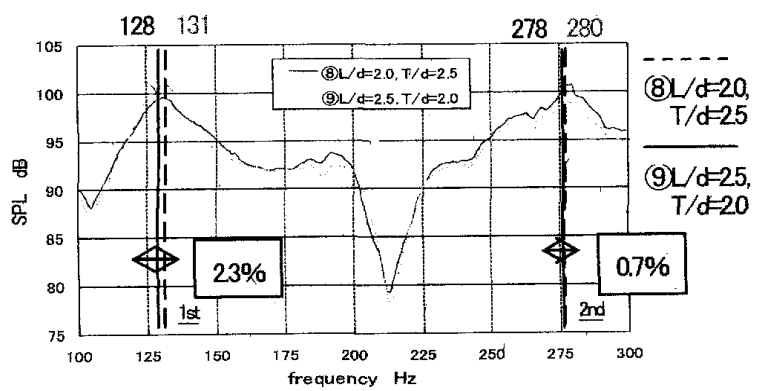

Fig.20 Comparison of resonant frequency at $\mathrm{L} / \mathrm{d}=2.0, \mathrm{~T} / \mathrm{d}=2.5$ with $\mathrm{L} / \mathrm{d}=2.5, \mathrm{~T} / \mathrm{d}=2.0$ in $\sigma=0.107$

ここで，音速と充填率の関係式である式(16)にお いて 3 章で述べた補正をおこなった式(17)，(18)に， 充填率 $\sigma$ が 0.3 以上のである本実験ケース $\sigma=0.306$ をあてはめた。すると補正係数 $\mathrm{a}=1$ (補正を扝こな つていない場合）では上記の通り，実験值と予測值 の誤差 $(1 \mathrm{st} 6 \%$ ，2nd $3 \%)$ に対して，補正係数 
$\mathrm{a}=1.35$ では，誤差(1st2.5\%，2nd 1\%)3\%以内と小さ くなった.このことからも 3 章で述べた式(17)， (18)の有用性が示せた。

\section{(2)共鳴周波数と充填率の関係}

正方配列において比較すると，図 18 に示すよう に1次，2次モードとも高充填率ほど共鳴周波数の 值が小さくなることがわかる.これは理論式(16)か らも妥当であることが言える. 図 19，20は流れ方 向ピッチし，流孔值角方向ピッチ T潩なるが同充 填率でのケースを比較したものである．流れ直角方 向ピッチ Tが小さい方が共鳴周波数の值が小さく なる，また図 19 と図 20 はそれぞれ充填率 $\sigma$ が 0.255 と 0.107 の異配列での共鳴周波数を比較したも ので，これらより高充填率（ $\sigma=0.255 ）$ の方が共鳴 周波数の值の差，才なわち減少率が大きい（。 $=0.255$ : 1st-3.2\%, 2nd-1.9\%， $\sigma=0.107$ : 1st-2.3, 2nd-0.7\%).これらは表 5〜 7に示すようにFEMに よる解析からも端部効果等の影響による実験值と解 析値との值の誤差はあるが，同じ傾向がタられた。 また，表 5〜 7に示すように各比較詨象（充填率の） 違い: 表 5，7, 配列の違い: 表 6) での共鳴周波数 の值の変化の比率 (各表の最下段) においても実測 值と予測值でほぼ同様の結果が得られた。

Table 5 Comparison of resonant frequency between analysis and measurement( $\sigma=0.136$ and 0.212)

\begin{tabular}{|c|c|c|c|c|}
\hline & \multicolumn{3}{|c|}{ Analysis value $(\mathrm{Hz}) /$ Exp.value $(\mathrm{Hz})$} \\
\hline & \multicolumn{2}{|c|}{1 st } & \multicolumn{2}{c|}{ 2nd } \\
\hline $3 \mathrm{~L} / \mathrm{d}=\mathrm{T} / \mathrm{d}=2.5(\sigma=0.136)$ & 152 & 132 & 304 & 279 \\
\hline $4 \mathrm{~L} / \mathrm{d}=\mathrm{T} / \mathrm{d}=2.0(\sigma=0.212)$ & 150 & 130 & 300 & 277 \\
\hline$(4 / 3$ & $\begin{array}{c}150 / 152 \\
10.99)\end{array}$ & $\begin{array}{c}130 / 132 \\
(0.98)\end{array}$ & $\begin{array}{c}300 / 304 \\
(0.99)\end{array}$ & $\begin{array}{c}277 / 279 \\
(0.99)\end{array}$ \\
\hline
\end{tabular}

Table 6 Comparison of resonant frequency between analysis and measurement $(\mathrm{L} / \mathrm{d}=1.5, \mathrm{~T} / \mathrm{d}=2.5$ and $\mathrm{L} / \mathrm{d}=2.5, \mathrm{~L} / \mathrm{d}=1.5$ at $\sigma$ $=0.204$ )

\begin{tabular}{|c|c|c|c|c|}
\hline & \multicolumn{3}{|c|}{ Analysis value $(\mathrm{Hz}) /$ Exp.value $(\mathrm{Hz})$} \\
\hline & \multicolumn{2}{|c|}{1 st } & \multicolumn{2}{c|}{ 2nd } \\
\hline $6 \mathrm{~L} / \mathrm{d}=1.5 . \mathrm{T} / \mathrm{d}=2.5(\sigma=0.204)$ & 151 & 128 & 303 & 281 \\
\hline $\mathrm{T} \mathrm{L} / \mathrm{d}=2.5 . \mathrm{T} / \mathrm{d}=1.5(\sigma=0.204)$ & 148 & 127 & 297 & 273 \\
\hline $\boldsymbol{Z} / 6)$ & $\begin{array}{c}148 / 151 \\
(0.98)\end{array}$ & $\begin{array}{c}127 / 128 \\
(0.99)\end{array}$ & $\begin{array}{c}297 / 303 \\
(0.98)\end{array}$ & $\begin{array}{c}273 / 281 \\
(0.99)\end{array}$ \\
\hline
\end{tabular}

Table 7 Comparison of resonant frequency between analysis and measurement $(\mathrm{L} / \mathrm{d}=2.0, \mathrm{~T} / \mathrm{d}=2.5$ and $\mathrm{L} / \mathrm{d}=2.5, \mathrm{~L} / \mathrm{d}=2.0$ at $\sigma$ $=0.107$ )

\begin{tabular}{|c|c|c|c|c|}
\hline & \multicolumn{3}{|c|}{ Analysis value $(\mathrm{Hz})$} & Exp.value $(\mathrm{Hz})$ \\
\hline & \multicolumn{2}{|c|}{1 st } & \multicolumn{2}{|c|}{ 2nd } \\
\hline $8 \mathrm{~L} / \mathrm{d}=2.0 . \mathrm{T} / \mathrm{d}=2.5(\sigma=0.107)$ & 152 & 131 & 303 & 280 \\
\hline $9 \mathrm{~L} / \mathrm{d}=2.5 \mathrm{~T} / \mathrm{d}=2.0(\sigma=0.107$ & 150 & 128 & 301 & 278 \\
\hline $9 / 8$ & $\begin{array}{c}150 / 152 \\
(0.99)\end{array}$ & $\begin{array}{c}128 / 131 \\
(0.98)\end{array}$ & $\begin{array}{c}301 / 303 \\
(0.99)\end{array}$ & $\begin{array}{c}278 / 280 \\
(0.98)\end{array}$ \\
\hline
\end{tabular}

\section{6. 䊅 言}

管群を有するダクト内音場の音速を評価するため
に，FEMによる解析と実験を行い，理論式の有用性 を检討した. その結果以下のことが明らかになった.

（1）今回の実験およびFEMによる解析に基づく検討 の範囲では，Parker やBlevins が提唱した音速 $\mathrm{c}$ と充填率 $\sigma$ の関係式の理論式

$$
\frac{f_{n}}{f_{n 0}}=\frac{1}{\sqrt{1+\sigma}} \frac{c}{c_{0}}
$$

は，充填率の大きな領域では誤差が大きくなり， 補正式を導入することで，よりよい一致が得ら れる。また，格子配列にお心ては，充填率が同 じであれば，流れ直角方向ピッチが大きい場合 の方が比較的よく一致することが確認された.

（2）（1）の結言においいて補正が必要となる充填率 $\sigma$ の值は 0.2 以上であり，その場合は

$$
\frac{f_{n}}{f_{n 0}}=\frac{1}{\sqrt{1+a \sigma}} \frac{c}{c_{0}}
$$

の式において $a=(10 / 3) \sigma+1 / 3$ とすれば解析 結果及び実験結果と予測值がよく合う。

（3）同充填率である格子配列においては，流れ直角 万向ピッチ $\mathrm{T} / \mathrm{d}$ が小さいもの方ほど，音速がわ ずかに小さくなることが実験，解析で得られた。

（4）同充填率である千鳥配列においては，配列パタ ーンの共鳴周波数の值に及ぼす影響はわずかで ある。

\section{文献}

(1) R. Parker, Acoustic Resonances in Passages Containing Banks of Heat Exchanger Tubes, Jononal of Sound and Vibration, 57, (1979), pp.245-260

(2) R.D.Blevins, The Effect of Sound on Vortex Shedding from Circular Cylinders, Journal of Fluid Mechanics, 161, (1985), pp.217-237

(3) R.D.Blevins, Acoustic Modes of Heat Exchanger Tube Bundles, Journal of Sound and Vibration, 109(1), (1986), pp.19-31

(4) K. Ishihara, Study on High SPL Sound of Gas Heater Composed of Two Parallel Located Ducts with Tube Bundles（1st Report, Understanding of Phenomenon) , Transaction of the JSME, 70-689, B (2004.1), pp.126-132

(5) H.Shiraki, Noise Protection Design and Simulation, Ohyo Gizyutu Syzppan, 198

(6) M.C.QUINN and M.S.HOWE, The influence of mean flow on the acoustic properties of a tube bank, Proceedings of the Royal Society of London, A396, (1984), pp.383-40 